\title{
The Role and Importance of Information Sources Case Study: The European Union's Diplomacy and the Middle East Crisis at the Beginning of the $21^{\text {st }}$ Century
}

\author{
Ana-Maria Bolborici \\ Transilvania University of Braşov, Romania
}

\begin{abstract}
This article is based on a case study: the analysis of the Israeli-Palestinian conflict in the regional and international context by emphasizing the role and importance of information sources in writing a doctoral thesis in the field of International Relations. As far as concerns the implication of Romanian authors / researchers in the debate on the implication of the European Union in the IsraeliPalestinian conflict, I have come to the conclusion that, although the main theme is a rather intense addressed issue, I have not managed to identify Romanian authors who have addressed the issue from the perspective of European diplomacy.
\end{abstract}

Keywords: International Relations, Israeli-Palestinian conflict, European Union, information sources. 


\title{
The Role and Importance of Information Sources Case Study: The European Union's Diplomacy and the Middle East Crisis at the Beginning of the $21^{\text {st }}$ Century
}

\author{
Ana-Maria Bolborici \\ Transilvania University of Braşov, Romania
}

\section{Introduction}

This paper is based on presenting a case study the analysis of the Israeli-Palestinian conflict in the regional and international context by emphasising the role and importance of information sources in a doctoral thesis in the field of International Relations. This analysis was the main subject of my PhD thesis and was successfully defended in 2011, at the BabesBolyai University, Faculty of History, in the field of International Relations. In March 2016, Institutul European, Iași (Romania) the book titled European Union Diplomacy and the Middle East Crisis at the Beginning of 21 st Century, which is based on my doctoral thesis.

I have chosen to focus my study on this subject for two main reasons: on the first hand, today's social-political reality of the present that generates multiple dilemmas and controversies which await relevant answers; on the second hand, it is remarkable that this theme is so fresh and generates such interest that it has caught the eye of the most important states of the world. Taking into account the degree of investigation of the current topic, we can begin by estimating that, at an international level, the Middle East conflict is a rather discussed and analyzed subject, the great number of conferences dealing with this idea (but also others relevant to the area) abundantly prove this. The interest for this region has been reflected by the multiple analysis perspectives of the specific area conflicts, which have been studied by numerous researchers.

At the Summit of the Book 2017, I decided to present a few aspects from "background" works, focusing on the fact that in the field of International Relations it is a real challenge to find and use valid, factual and objective information sources.

The theme of my book is based on the analysis of the Israeli-Palestinian conflict in the regional and international context and on the effort of the international community especially which is focused on solving the Middle East conflict.

I have chosen to focus on this subject, due to the current social-political realities of the present, which are generating multiple dilemmas and controversies, all which await relevant answers. Furthermore, this theme is remarkably fresh and of interest considering that the Middle East is already established as a classical power vacuum model, which has caught the eye of the most important states of the world (geopolitical and geostrategic).

Taking into consideration the degree of investigation of the current theme, and considering that on an international level, the Middle East conflict is a much debated and analyzed subject, a fact proven by the large number of conferences dedicated to this issue. 
The interest for this region has been reflected by the multiple analysis perspectives of the conflicts specific to the area, which have been studied by numerous researchers. ${ }^{1}$

In the last few years, we have come to the conclusion that even on the Romanian territory the problems specific to the Middle East have stirred to some extent the interest of the researchers.

As far as the implication of Romanian authors or researchers in the debate is concerned, the conclusion is that although the crisis in the Middle East is an intensely addressed issue, managing to identify Romanian authors ${ }^{2}$ who have addressed the issue from the perspective of European diplomacy is difficult.

Trying to clarify to what extent this theme was treated on the national level, the $\mathrm{PhD}$ theses presented in the last few years in Romanian universities have led to the conclusion that even in Romania the specific problems of the Middle East interest in researchers. ${ }^{3}$

Every author starts their book by building their own chronology. Even though the title of the paper The European Union diplomacy and the Middle East Crisis at the Beginning of

\footnotetext{
${ }^{1}$ In order to argue this, I mention only a few recent papers which have been used in documenting my book and which constitute of dissertations or PhD projects: Rouba Al-Fattal, The Foreign Policy of the EU in the Palestinian Territory, Centre for European Policy Studies, CEPS Working Document No. 328/May 2010; Levi, Idan, The EU Policy in the Middle East. Problematic Nature and Potential Role", Dissertation zur Erlangung des Grades des Doktors der Philosophie im Fachbereich Sozialwissenschaften der Universität Hamburg, 2005; Hamntan, Michail, The EU's External Relations deficit towards the Middle East, Katholieke Universiteit Leuven, Faculty of Social Sciences, Department of Political Science, Academic Year 2004-2005.

2 I will mention some titles who reflect and analyse in some way the issues of the zone, in this respect: Gavrilă Carmen, Revolta Orientului (Bucharest: Polirom, 2013); Raluca Popa, Secretele Orientului Mijlociu [The Secrets of the Middle East] (Niculescu Publishing, 2011); Dumitru Chican, România și Orientul Mijlociu in oglin ri paralele [Romania and the Middle East in parallel mirrors] (Baia Mare: Proema Publishing, 2010); Raluca Rus, Intre mit și realitate. Lupta pentru Țara Sfântă [Between myth and reality. The fight for the Holy Land] (Iasi: Lumen Publishing, 2009); Traian Stambert, Faţa ascunsă a conflictului din Orientul Mijlociu [The hidden face of the Middle East conflict] (Bucharest: PACO Publishing, 2009); Raluca Rus, România și conflictul israliano-palestinian [Romania and the Israeli-Palestinian conflict] (Iasi: Lumen Publishing, 2008); Valentina Tania Secheşan, Problema kurdă in contextul crizelor irakiene [The Kurdish problem in the context of the Iraqi crisis] (Iasi: Lumen Publishing, 2008); Constantin Moștoflei, Vasile Popa, Rolul UE in asigurarea securitații globale [The role of the EU in guaranteeing global security] (Bucharest: National Defence University „Carol I” Publishing, 2008); Raluca Rus, Conflictul din Orientul Apropiat in perioada 1948-2000 [The Near East conflict during 1948-2000] (Iasi: Lumen Publishing, 2006).

${ }^{3}$ Some relevant papers which support this idea are: Sandovici Dănuț-Florin, Dinamica arbitecturii de securitate a Orientului Mijlocin in contextul transformărilor regionale incepute in 2011 [The dynamics of the Middle East security architecture in the context of regional transformations which started in 2011] (Bucharest: National Defence University „Carol I”, 2015); Lucian Sanda, Dimensiunile internationale ale conflictului israeliano-palestinian [The international dimensions of the Israeli-Palestinian conflict] (Bucharest: University of Bucharest, 2010); Yehuda Meir Roth, Leadership sub asediu, impactul 'proceselor Intifadei' asupra ofiţerilor de comandă ai unităților de teren Trabal și asupra ofițterilor in general [Leadership under siege, the impact of the "Intifada trials" on officers on the ground control units zahal and the on officers in general] (Cluj Napoca: Babeş-Bolyai University, 2010); Hanna Kovel, Examinarea funcţionării leadership-ului local la autoritătile locale, in vremuri de pericol, in timpul celui de-al doilea răžboi din Liban (iulieaugust 2006 [Examination of local leadership for local authorities during time of danger, the $2^{\text {nd }}$ Lebanon war (July - August 2006)] (Cluj Napoca: Babeş-Bolyai University, 20100; Essam Abou Salem, Conflictele contemporane și modalităţi de reglementare a acestora (în baz̧a conflictelor transnistrean şi palestinoisraelian) [Contemporary conflicts and ways of handling them (the Transnistrian and Israeli-Palestinian conflicts] (Chişinău: The Moldovian State University, 2006).
} 
the 21 st century" places our timeline at the beginning of the present century, I decided to approach the Israeli-Palestinian conflict from a historical perspective, having regard for the evolution of the Jewish people in relation to Palestine through the historical period between 2000-1000 B.C.

In this way, what are presented are the most important steps which the two entities (Israeli and Palestinian) had to go through. Therefore, I think the present theme of the paper was better designed for starting from the historical perspective, which I consider to be fundamental for understanding the Israeli-Palestinian conflict today and the way the European Union understands intervention in this region.

Looking back this work appears as a sum of information covering both the theoretical and practical issues concerning the European Union's organizational architecture, specifically instruments and policies, particular elements of the Israeli-Palestinian crisis.

I consider these issues to be essential, but for a better understanding of the reasons for the Israeli-Palestinian conflict we need a careful and thorough analysis of the causes that have led to the conflict between the two sides in what is generally known as the Middle East crisis and also an analysis of the evolution of the peace process during history. The theme of my research requires not only to identify the causes and factors that have caused delays in the peace process but also have imposed, at the same time, a recognition of present realities when we intend to highlight and analyse the effort of European diplomacy in management of the Israeli-Palestinian crisis, starting with the European community.

\section{Methodology and information sources}

The methodology used for this book is based primarily on a diversified bibliography which we believe justifies the final conclusions, thus focusing on the study of primary sources such as: treaties, laws, official reports from various international organizations, interviews, press statements of Heads of State and Government on the occasion of high level meetings, press releases and press releases of officials, secondary sources: specialty books, manuals, dictionaries, studies and articles published in national or international journals, on historical reality, on the points of view of International Relations specialists, whose work is based on a thorough scientific documentation.

For the secondary information sources, I have used: speciality books, manuals, dictionaries, studies and articles published in national or international magazines: regarding the historical reality based on the points of view of International Relations specialists, researchers whose papers are based on a scientific documentation. Among the strategies adopted to synthesize this book, I must mention that the summary of events that mark the context of Israeli-Palestinian crisis are highlighted in their importance to the further development of the peace process; by presenting the existing realities, which describe the evolution of the relationships developed by European Union with Israel and the Palestinian Authority in the context of the crisis this will be done in a fair and pragmatic report to put together realistic predictions and scenarios for the evaluation of proposed solutions over time, but also those of recent date, in order to end the Israeli-Palestinian conflict.

In the second part, my research is based on a content analysis of the answers given by 25 specialists in the field of International Relation. In the collection of the answers I have been using the Delphi method, whose specificity is to apply the successive questionnaires to 
the respondents. Regarding the sociological approach, and in collecting responses, I have used The Delphi ${ }^{4}$ method.

I consider that the main merit of my approach derives from the research which was conducted with the aid specialists in the Middle Eastern, especially on the Israeli-Palestinian crisis; they have encouraged my initiative and have offered me specialized answers about the Israeli-Palestinian conflict, as well as assessments regarding the role of the European Union's diplomacy in managing and resolving the conflict. To my knowledge, this type of investigation has not been done until now in Romania and especially not as a doctoral thesis to be presented to the public.

Initially, the questionnaire was sent over the course of a year to a total number of 195 respondents: specialists, professors, diplomats and politicians from different countries (including Romania), which are interested and have researched the Israeli-Palestinian conflict and the Middle East region, in general.

I mention that a number of institutions and persons kindly provided a number of bibliographic materials without which I would not have been able to complete the doctoral thesis.

In preparing my concluding analysis, found in the last chapter of the book, I used as a study material the received answers to a questionnaire, from a twenty-five specially trained respondents who come from different socio-geographic areas mainly focused on the Middle East's regional problems.

In this context, I want again to give thanks to the twenty-five respondents of whom are researchers and practitioners from around the world, who responded to this questionnaire, in spite of distance and anonymity.

Considering the hypothesis from which I started to develop the present paper, I have proposed to analyse: if deliberation about a real and effective diplomacy at the European Union level is active and working in parallel in the Middle East region in order to solve the Israeli-Palestinian conflict and whether it can have a decisive contribution considering the general effort of the international communities in this direction.

In the subchapter "Final conclusions", as I already underlined, starting from the question "Is peace really wanted in the Near and Middle East? And if so, who can have a decisive contribution in this respect?", I concluded by starting from the analysis of the role of the European Union's diplomacy in solving the Israeli-Palestinian conflict. Surely, these answers are important when thinking about the future of the Middle and Near East.

\section{Conclusions}

Coming back to the role and the importance of the sources, one of the historians' important rules is the bias rule and in this regard, thinking every source is biased in some way. Documents usually offer only what the author of the document thought happened, or perhaps only what they want us to think happened. As a result, historians follow these bias rule guidelines when they review evidence from the past: every piece of evidence and source must be read or analyse critically and each piece of evidence and source must be crosschecked and compared with related sources and pieces of evidence.

But not only do historians have to respect this rule, also the journalists, publishers, and authors, for real and concrete information for the people who pay for finding and reading well-documented and truthful quality analysis.

\footnotetext{
${ }^{4}$ In my research I applied only half of the Delphi method, because of the status of the parties involved and; secondly, the slow the evolution of the situation in the region does not permit me to repeat the analysis of using the questionnaire on these people.
} 
Nowadays, the internet is the main source of information, but there is a very clear dividing line between the young and the old with the middle aged; the statistics show that for those younger than or 45 years old, the internet is the dominant source of information while the internet plays only a modest role for older generations. ${ }^{5}$

Among students, 98 percent use the internet for schoolwork, 79 percent once a week and 35 percent daily. The internet thus plays a large role and this applies especially to adult students; half $(59 \%)$ of older students (26-35) use the internet daily to retrieve information about papers school work, $43 \%$ of the ages between $16-25$ and $23 \%$ of school children between the ages of 12 to $15 .{ }^{6}$

Almost two out of three people $(69 \%)$ use the internet for cultural, scientific and literary; there is a difference among the young that is based on education but it increases for those over 45 years old. Among the middle-aged and the elderly, it is three times more likely than those with a higher education, compared to those who have not graduated, who use the internet for culture, science and literature. ${ }^{7}$

Primary sources are the original documents of an event or discovery, that is, results of research, experiments or surveys, interviews, letters, diaries, legal documents, and scientific journal articles. Primary sources are also records of events as they are first described; this may include videotapes, audio recordings or eyewitness news reports. ${ }^{8}$

Also important for the architecture of the book are the secondary sources which offer an analysis or a restatement of an event or discovery described in primary sources; these often interpret, explain or summarize primary sources. Some secondary sources are used to persuade the reader and that is why secondary sources may be considered less objective than the primary sources. Examples of secondary sources include: dictionaries, encyclopaedias, textbooks, articles and editorials that interpret or review research works. ${ }^{9}$

"The study of historical sources and artefacts play an important role in the field of history, as well, anthropology and urban sociology are useful fields to consider. These sources and resources offer sound arguments in favour of examining aspects of mundane or private life." 10

From personal experience, I recognize that is easier to find final sources primarily on the internet. It also is very hard to compose a rigorous selection of well documented and valid sources. Otherwise, the researcher is risking to enter into a world of speculation.

It's clear that now fewer people use libraries than in the past, but they're still visited by over a third of the adult population. ${ }^{11}$ And although more students are using digital libraries than paper-based libraries, the library building as a place to study, is still important to them. Similarly, while open access content, digitization program and e-book subscriptions may

\footnotetext{
5 The Swedes and the internet 2014. An annual study of the Swedish people's internet habits, http:/ / en.soi2014.se/information-and-facts/internet-is-the-most-important-source-of-information/. Accessed: 09.10.2017.

${ }^{6}$ Idem.

7 Idem.

8 University of Michigan-Flint, Identifying Information Sources, https://www.umflint.edu/library/identifying-information-sources. Accessed: 09.10.2017.

9 Idem.

${ }^{10}$ Mariana Borcoman, "Techniques and tools used in archive work applicable to teaching process," in Advanced Educational Technologies International Conference (2010), 6th WSEAS / Iasme (Edute'10), Katouni, Sousse, Tunisia, p. 102.

11 Frankie Wilson, Hard Evidence: How Many People Actually Use Libraries? March 14, 2016, http:/ / theconversation.com/hard-evidence-how-many-people-actually-use-libraries-55671. Accessed: 16.10.2017.
} 
mean that a public library is not the only place to read books and newspapers, people still enjoy the experience of physical books and value the space to escape, study and learn.

Every academician, researcher or author, no matter the field of study, must pay more attention to those every source, documents and be used with precaution. As Sorea considers, orientation in the vast and overwhelming field of available information requires connotations of initiation. ${ }^{12}$

Will the printed-book or the e-book will be most used in the next decade? The e-books became in popularity once they became as easy and enjoyable to read as printed books. Although printed books remain the most popular means of reading, over the past decade ebooks have made a valiant effort at catching up. Are threatened the traditional books with extinction or will coexist with the ebooks? Answers to these questions do not come easily, regarding the possible future for the paper book in the age of digital proliferation.

\section{References}

Bolborici, Ana-Maria. European Union Diplomacy and the Middle East Crises at the Beginning of 21st Century. Iasi: European Institute, 2016.

Borcoman, Mariana. "Techniques and tools used in archive work applicable to teaching process." In the Proceedings of the Advanced Educational Technologies, $6^{\text {th }}$ WSEAS /Iasme (Edute'10), Katouni, Sousse, Tunisia.

Sorea, D. "Communicational Tools of Self-Knowledge." In Bulletin of the Transilvania University of Brasov, Series VII: Social Sciences and Law, 5 (54) No. 1 (2012): 77-82.

Wilson, Frankie. Hard Evidence: How Many People Actually Use Libraries? March 14, 2016, http://theconversation.com/hard-evidence-how-many-people-actually-use-libraries55671. Accessed: 16.10.2017.

Online sources:

The Swedes and the internet 2014. An annual study of the Swedish people's internet habits. http://en.soi2014.se/information-and-facts/internet-is-the-most-important-source-ofinformation/. Accessed: 09.10.2017.

University of Michigan-Flint, Identifying Information Sources, https://www.umflint.edu/library/identifying-information-sources. Accessed: 09.10.2017.

\footnotetext{
12 Sorea, D., "Communicational Tools of Self-Knowledge," in Bulletin of the Transilvania University of
} Brasov, Series VII: Social Sciences and Law, 5 (54) No. 1 (2012): 77-82. 